\title{
Mixed Germ Cell Tumor of the Pituitary-Hypothalamic Region Presenting as Craniopharyngioma: Case Report and Review of the Literature
}

\begin{abstract}
Craniopharyngiomas and germ cell tumors (GCT) may affect the pituitaryhypothalamic region during childhood. Although different in origin, their clinical and radiological features may be similar. In this article we present a 5-year-old girl with clinical and radiological findings (computer tomography calcification) that were initially considered as craniopharyngioma. However clinical outcome, blood and cerebral spinal fluid tumoral markers, and results from anatomopathology and immunohistochemistry disclosed a mixed GCT. This case report highlights that some clinical features and radiological findings of pituitary-hypothalamic tumors may be misdiagnosed as craniopharyngioma mainly when there is a mature teratoma with cartilaginous tissue differentiation. (Arq Bras Endocrinol Metab 2008; 52/9:1501-1504)
\end{abstract}

Keywords: Germ Cell Tumor; Craniopharyngioma; Pituitary; Hypothalamus

\section{RESUMO}

Tumor Misto de Células Germinativas da Região Hipotálamo-Hipofisária Apresentando-se como Craniofaringioma: Relato de Caso e Revisão da Literatura.

Craniofaringiomas e tumores mistos de células germinativas (TCG) podem acometer a região hipotálamo-hipofisária durante a infância. Embora tenham diferentes origens, as manifestações clínicas e achados radiológicos podem ser semelhantes. Nosso objetivo é relatar o caso de uma paciente de 5 anos de idade, cujas manifestações clínicas e achados radiológicos (presença de calcificações à tomografia computadorizada [TC]) foram inicialmente considerados como provável craniofaringioma. No entanto, a piora clínica progressiva, marcadores tumorais séricos e liquóricos elevados, assim como os resultados do estudo anatomopatológico e imunoistoquímico revelaram tratar-se de TCG. Este caso enfatiza que alguns achados clínicos e radiológicos de tumores da região hipotálamo-hipofisária podem ser erroneamente diagnosticados como craniofaringiomas, principalmente se houver presença de teratoma maduro com diferenciação em tecido cartilaginoso. (Arq Bras Endocrinol Metab 2008; 52/9:1501-1504)

Descritores: Tumor de células germinativas; Craniofaringioma; Hipófise; Hipotálamo

\section{INTRODUCTION}

rimary germ cell tumors (GCT) of the central nervous system (CNS) are a rare and heterogeneous group of neoplasias with distinct histological subtypes. They are generally located in the midline and 40\% involve the suprasellar region. Prevalence is higher in the early decades of life (1) where they comprise $0.5 \%$ to $3.0 \%$ of brain tumors $(2)$. GCT may be classified into germi- clinical case report

\section{Claudia Veiga Chang \\ VÂNIA dos SANTOS NUNES \\ Andre Carvalho Felicio \\ MARCo ANTONIO ZANINI \\ Malebranche B. C. Cunha-Neto \\ ana Valeria Barros de Castro}

Faculdade de Medicina de Botucatu (Unesp) (CVC, VSN, MAZ, AVBC), Botucatu, SP, Brasil; Departamento de Neurologia da Universidade Federal de São Paulo (Unifesp) (ACF); Unidade de Neuroendocrinologia da Divisão de Neurocirurgia, Hospital das Clínicas da Faculdade de Medicina da Universidade de São Paulo (FMUSP) (CVC, MBCC), São Paulo, SP, Brasil.

Received in 3/2/2008 Acepted in 5/9/2008 
nomatous or nongerminomatous tumors. The former derive from primordial primitive cells corresponding to the most undifferentiated lineage and the latter originates from totipotent neoplastic germ cells, embryonal cells (teratoma or embryonal carcinoma) or non-embryonal cell elements (endodermal sinus tumor and choriocarcinoma) (3). Usually, tumors derived from the earlier stages of histogenesis (endodermal sinus tumor or choriocarcinoma) are more malignant than tumors from later stages (germinomas) $(1,4,5)$.

Craniopharyngiomas, on the other hand are benign epithelial tumors of the CNS originating from embryonal remnants of Rathke's pouch. Growth is insidious mainly affecting the sellar and suprasellar regions. They have two prevalence peaks, one in the first two decades and another in the seventh and eighth decades of life. Craniopharyngiomas make up 6\% to $10 \%$ of all intracranial tumors and are the most prevalent in the pituitary-hypothalamic region of children (6). Although usually benign, they may have an aggressive local behavior but rarely become malignant (7-9).

In this article we report the case of a young girl with a mixed GCT of the pituitary-hypothalamic region that presented clinical and radiological features resembling craniopharyngioma.

\section{SUBJECTS AND METHODS}

\section{Case Report}

A 5-year-old girl was admitted with a 20-day history of headache, nausea, vomiting, and progressive visual field loss. She also presented hyperphagia, polyuria, and polydipsia. On physical examination height and weight were at the 50th percentile and she was in prepubertal status. Neurological exam showed bilateral blindness. Endocrinological evaluation disclosed central hypothyroidism, hypocortisolism, and diabetes insipidus. Despite lower IGF-1 levels $(89 \mathrm{ng} / \mathrm{ml}$; Reference value $=\mathrm{RV}=242 \mathrm{ng} / \mathrm{ml}-2$ standard deviations $=50 \mathrm{ng} /$ $\mathrm{ml}$ ) the patient did not have stature deficit. With the purpose to improve clinical outcome pre-surgical treatment was initiated with hydrocortisone, levothyroxine, and desmopressin. Sellar magnetic resonance imaging (MRI) disclosed a heterogeneous mass located in the sellar, supra, and infrasellar regions (Figure 1), and a hyperintense area suggestive of intratumoral hemorrhage together with calcifications that were confirmed in the sellar computer tomography $(\mathrm{CT})$.

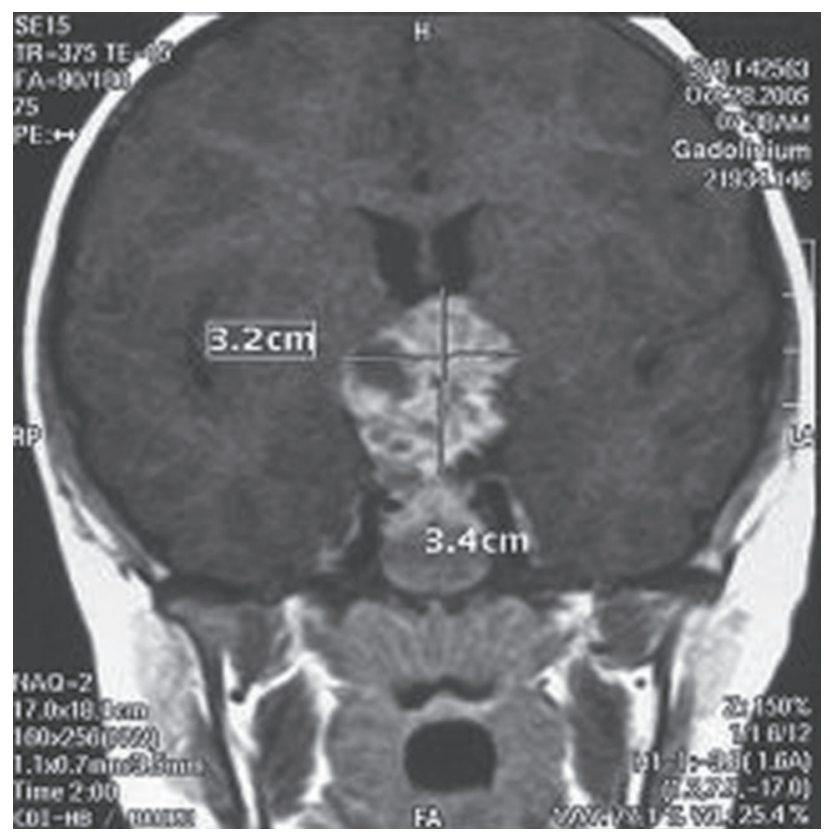

Figura 1. Sellar magnetic resonance imaging on coronal view showing a heterogeneous mass located in the sellar, supra and infrasellar regions.

Ten days after admission, her clinical and neurological status worsened (Glasgow Coma Scale $=8 / 15$ ) and she developed refractory hyperthermia without evidence of infectious disease. A brain CT revealed acute hydrocephalus. Due to the tumoral aggressive behavior and atypical outcome the hypothesis of GCT was made and the following tumoral markers were evaluated. Seric human chorionic gonadotrophin (HCG- $\beta$ ) and alpha-fetoprotein (AFP) levels were, respectively, $1300 \mathrm{mIU} / \mathrm{mL}$ (reference value $\mathrm{RV}<5 \mathrm{mIU} / \mathrm{mL})$ and $227 \mathrm{ng} / \mathrm{mL}(\mathrm{RV}<$ $7 \mathrm{ng} / \mathrm{mL}$ ). On the cerebral spinal fluid (CSF) (collected after surgery) the same tumoral markers, HCG- $\beta$ and AFP, were $3802 \mathrm{ng} / \mathrm{dL}$ and $137 \mathrm{ng} / \mathrm{mL}$, respectively ( $\mathrm{RV}$ on the CFS=not detectable).

She was without delay submitted to neurosurgery and partial resection of the tumor was performed. The anatomopathology and immunohistochemistry evaluations showed mixed GCT with germinomatous component, mature teratoma, and doubtful embryonal carcinoma component. After surgery she presented mild recovery from hyperthermia but remained in poor neurological condition. Chemotherapy with cisplatin, etoposide, and iphosphamide was initiated. She developed acute renal failure and bone marrow aplasia, and died 21 days after beginning chemotherapy. The patient relatives signed an informed consent allowing data publication. 


\section{DISCUSSION}

This case report highlights that some clinical features and radiological findings of pituitary-hypothalamic tumors may be misdiagnosed as craniopharyngioma. Furthermore, sudden worsening of clinical and neurological status should draw attention to rapid tumor growth, which is not typical of craniopharyngiomas (6). In these situations either the diagnosis of malignant change of craniopharyngioma or GCT should be postulated.

Malignant change of craniopharyngiomas is rare and the mechanism of this process remains elusive (79 ). Some authors propose that radiotherapy could be in part responsible (8), but since many patients are submitted to adjuvant radiotherapy without developing this complication, it is unlikely to be the main factor $(10)$.

Similar to craniopharyngiomas, GCT may also affect the suprasellar region during childhood $(1,5,11$ 13) leading to the same clinical manifestations. Nada and cols. (12) reported a similar case to ours in which a 15-year-old boy presented visual impairment, diabetes insipidus and hypopituitarism. MRI was suggestive of a large suprasellar and retrosellar craniopharyngioma and histopathology of the first surgical specimen was interpreted as craniopharyngioma. In a second histological examination, however, it was shown derivatives of all three germ cell lineages along with areas of embryonal carcinoma, and yolk sac tumor besides squamous cysts, establishing the diagnosis of malignant mixed germ cell tumor. Serum and CSF were strongly positive for AFP.

Moreover, craniopharyngiomas and GCT also share the same radiological features since mature teratomas may differentiate into cartilaginous tissue presenting on CT as a hyperdense lesion suggesting calcification. Another relevant factor of the case aforementioned was the presence of a hemorrhagic area, which is rare not only in craniopharyngiomas but also in GCT tumors $(14,15)$. Intratumoral hemorrhage of craniopharyngiomas tends to occur after over 15 years of tumor maturation and the squamous-papillary type tend to bleed more than the adamantinomatous type (15).

If serum or CSF tumoral markers are elevated (HCG- $\beta$ and AFP), GCTs may be classified as secreting tumors presenting a strong relationship to histological subtype $(13,16)$ and generally have poor prognosis. In our case, after clinical worsening elevated HCG- $\beta$ and AFP were important for the presurgical diagnosis of GCT.
According to some authors biopsy is essential for GCT diagnosis $(4,16)$. However, the small quantity of tumor specimen in mixed tumors may not be enough for the complete tumor characterization (17-20). In our case, surgical removal of the tumor was not sufficient to provide its full characterization. In our opinion the elevated levels of serum and CSF HCG- $\beta$ could be explained by the presence of syncytiotrophoblast secreting cells, or more probably, HCG- $\beta$ secreting choriocarcinoma that were not present in the specimen fragment.

Treatment of GCT is still controversial and includes surgery, radio- and chemotherapy. Currently, combined therapy is the treatment of choice $(1,4,17$, $20,21)$ due to tumor responsiveness to platinum-based chemotherapies $(22,23)$ and smaller doses of radiotherapy $(19,24)$.

Whether chemotherapy should be performed before or after neurosurgery is also controversial, except in urgent situations, such as in our case where the patient had sudden impairment of consciousness level due to acute hydrocephalus. Even with adjuvant platinum-based chemotherapy our patient worsened her clinical and neurological status, not only due to tumor growth but also to side effects from chemotherapy (acute renal failure and bone marrow aplasia).

In conclusion, the clinical features and radiological findings of pituitary-hypothalamic tumors may be similar in both craniopharyngioma and GCT. Despite reduced mortality rates with the advent of chemotherapy, GCT is still considered as very aggressive and the chemotherapy itself may cause serious complications. Therefore, more studies with larger numbers of cases are needed to address these questions and determine the best treatment options for minimizing the side effects of adjuvant therapy and providing longer survival.

No potential conflict of interest relevant to this article was reported.

\section{REFERENCES}

1. Brandes AA, Pasetto LM, Monfardini S. The treatment of cranial germ cell tumours. Cancer Treat Rev. 2000;26:233-42.

2. Smith $A A$, Weng $E$, Handler M, Foreman NK. Intracranial germ cell tumors: a single institution experience and review of the literature. J Neurooncol. 2004;68:153-9.

3. Kleihues P, Burger PC, Scheithauer BW. The new WHO classification of brain tumours. Brain Pathol. 1993;3:255-68.

4. Matsutani M, Sano K, Takakura K, Fujimaki T, Nakamura O, Funata N, et al. Primary intracranial germ cell tumors: a clini- 
cal analysis of 153 histologically verified cases. J Neurosurg. 1997;86:446-55.

5. Sano K. Intracranial dysembryogenetic tumors: pathogenesis and their order of malignancy. Neurosurg Rev. 2001;24:162-7.

6. Halac I, Zimmerman D. Endocrine manifestations of craniopharyngioma. Childs Nerv Syst. 2005;21:640-8.

7. Kristopaitis T, Thomas C, Petruzzelli GJ, Lee JM. Malignant Craniopharyngioma. Arch Pathol Lab Med. 2000;124:1356-60.

8. Nelson GA, Bastian FO, Schlitt M, White RL. Malignant transformation in craniopharyngioma. Neurosurgery. 1988;22:427-9.

9. Plowman PN, Besser GM, Shipley J, Summersgill B, Geddes $J$, Afshar F. Dramatic response of malignant craniopharyngioma to cis-platin-based chemotherapy. Should craniopharyngioma be considered as a suprasellar "germ cell" tumour? $\mathrm{Br}$ J Neurosurg. 2004;18(5):500-5.

10. Kalapurakal JA. Radiation therapy in the management of pediatric craniopharyngiomas-a review. Childs Nerv Syst. 2005; 21:808-16.

11. Jennings $M$, Gelman R, Hochberg F. Intracranial germ-cell tumors: natural history and pathogenesis. J Neurosurg. 1985;63:155-67.

12. Nada R, Mohan H, Dhir SP, Mukherjee KK, Kak VK. Suprasellar malignant mixed germ cell tumour presenting as craniopharyngioma. Neurol India. 2000;48:381-4.

13. Packer RJ, Cohen BH, Cooney K. Intracranial germ cell tumors. Oncologist. 2000;5:312-20.

14. Fernadez-Real JM, Villabona C, Acebes JJ, Gomez-Saez JM, Soler J. Pituitary apoplexy into nonadenomatous tissue: case report and review. Am J Med Sciences. 1995;310:68-70.

15. Haragushi K, Morimoto S, Tanooka A, Inoue M, Yoshida Y. Craniopharyngioma presenting a symptom of pituitary apoplexy and hyponatremia: a case report. No Shinkei Geka. 2000;28:1111-5.

16. Palmer RD, Nicholson JC, Hale JP. Management of germ cell tumors in childhood. Curr Paediatr. 2003;13:213-20.

17. Fouladi M, Grant R, Baruchel S, Chan H, Malkin D, Weitzman $\mathrm{S}$, Greenberg ML. Comparison of survival outcomes in pa- tients with intracranial germinomas treated with radiation alone versus reduced-dose radiation and chemotherapy. Childs Nerv Syst. 1998;14:596-601.

18. Ikura Y, Sasaki M, Ohgami M, Ikebe T, Gotoh K, Bettoh H, Sakurai M. Mixed germ cell tumour of the brain. Pathologic study of six autopsy cases. Pathol Res Pract. 1996;192:595-603.

19. Sawamura $Y$. Current diagnosis and treatment of central nervous system germ cell tumours. Curr Opin Neurol. 1996;9:419-23.

20. Nam DH, Cho BK, Shin HJ, Ahn HS, Kim HH, Wang KC. Treatment of intracranial nongerminomatous malignant germ cell tumor in children: the role of each treatment modality. Childs Nerv Syst. 1999;15:185-91.

21. Silvani A, Eoli M, Salmaggi A, Lamperti E, Fariselli L, Milanesi I, et al. Combined chemotherapy and radiotherapy for intracranial germinomas in adult patients: a single-institution study. J Neurooncol. 2005;71:271-6.

22. Calaminus G, Andreussi L, Garre ML, Kortmann RD, Schober $\mathrm{R}$, Gobel U. Secreting germ cell tumors of the central nervous system (CNS). First results of the cooperative German/Italian pilot study (CNS sGCT). Klin Pädiatr. 1997;209:222-7.

23. Gobel U, Bamberg M, Calaminus G, Gnekow AK, Herrmann $H D$, Lenard HG, et al. Improved prognosis of intracranial germ cell tumors by intensified therapy: results of the MAKEI 89 therapy protocol. Klin Padiatr. 1993;205:217-24.

24. Matsutani M, Sano K, Takakura K, Fujimaki T, Nakamura O. Combined treatment with chemotherapy and radiation therapy for intracranial germ cell tumors. Childs Nerv Syst. 1998; 14:59-62.

Correspondence to:

Claudia Veiga Chang,

Av. Bosque da Saúde, 834/193, Saúde

04142-081 São Paulo SP

Email: chang.cv@gmail.com 